
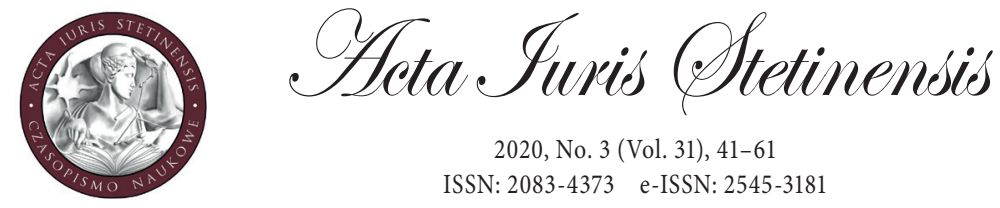

2020, No. 3 (Vol. 31), 41-61

ISSN: 2083-4373 e-ISSN: 2545-3181

DOI: 10.18276/ais.2020.31-03

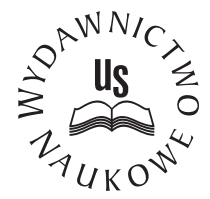

Katarzyna Kamińska

Ph.D. student

University of Silesia in Katowice, Poland

Faculty of Law and Administration

e-mail: katarzynakaminska@us.edu.pl

OPEN ACCESS

ORCID ID: 0000-0002-4438-0127

\title{
Intercountry adoption in Polish family law
}

\begin{abstract}
The objective of this article is to present the intercountry adoption institutions in Polish family law. The objective is achieved by analysing the term 'adoption' by tracing it back to its origins in Imperium Romanum. Particular attention was paid to the recent amendment to the Penal Code, based on which the legal definition of the term 'adoption' was introduced (which is not the case of the Family and Guardianship Code) and to the differences between the terms 'intercountry adoption' and 'foreign adoption'. The article includes the analysis of Article $114^{2}$ of the Family and Guardianship Code and the essence of the intercountry adoption principle of subsidiarity. The purpose of the study was to show technical and organisational issues related to the concept of intercountry adoption, such as pre-adoption period or 'eligibility' of potential adopters. One of the conclusions was that the citizenship of the adopter does not determine the international type of adoption, but his/her place of residence outside Poland. Certain international legal documents were reviewed to see how the adoptee's welfare is protected under international law and to outline the genesis of the regulations in Article $114^{2}$ of the Family and Guardianship Code. The author's aim is to show the circumstances favourable to the adoption of a child by a foreign couple. At this point, it should be stated that the child's best interest should always remain the most important condition. Furthermore, when ruling in an adoption case, the court should protect the child's interests, but also pay attention to the regulations concerning the continuity of the child's upbringing as well as its ethnic, religious, cultural and linguistic identity. The above is related to the
\end{abstract}


contemporary issue of adoption by homosexual couples. Countries, such as Poland, which do not allow adoption by homosexual couples may challenge the eligibility of candidates on the grounds of infringement of fundamental rules of the Polish legal order. Furthermore, the article includes statistical data concerning intercountry adoption. Currently, the number of intercountry adoptions decreases not only in Poland, but worldwide. In Poland, it may be caused by the tightening of the eligibility criteria for adopters and adoptees with respect to intercountry adoptions and reduction in the number of centres authorised to effect such adoptions. In the last part of the study, the author developed the argument that the issues of intercountry adoption are part of the global problems related to poverty and inequality.

Keywords: intercountry adoption, child's welfare, adoptee, principle of subsidiarity, adopter

\section{Introduction}

The term 'obligation of maintenance' is used in the Family and Guardianship Code, ${ }^{1}$ but its equivalent - -'adoption' - - derived from the Latin word adoptio is more popular. In Roman law, adoption was one of the methods for introducing a stranger into the family and under the paternal power (patria potestas). ${ }^{2}$ Adoptio meant adoption of a child that was supposed to 'imitate the nature, ${ }^{3}$ therefore, the requirement was that the adopter had to be older than the adoptee by at least 'full maturity'. According to the law of Justinian, the established age limit was $18 .{ }^{5}$

Adoption is by its very nature a measure of personal family law, but it was not always the case. In different historical periods, adoption was used to derive economic profits, going far beyond the area of civil law. ${ }^{6}$ In light of the provisions of the Family and Guardianship Code, adoption has legal and family character. The existence of the legal adoption relationship is a formal act that occurs as a result of

1 Act of 25 February 1964 - Family and Guardianship Code, consolidated text: Dz.U. (Journal of Laws) of 2019, item 2086.

2 The adoption was effected as a legal act between the present 'male head of a family' (pater familias) and the adopter, causing the breaking of family bonds between the adoptee and his/her present family as well as gaining independence from the current father's power. More information: Kuryłowicz, M., Rozwój historyczny rzymskiej adopcji, "Studia Iuridica Lublinensia" 2011, No. 16, pp. 35-53.

3 In compliance with the Roman principle adoptio naturam imitatur.

4 However, it is worth noting that it was not always the case. For some period of time, according to the Roman law, an older person could be adopted by a younger one [author's note: the author would like to thank an anonymous reviewer for pointing this out].

5 Kolańczyk, K., Prawo rzymskie, Warszawa 2007, p. 245.

6 The procedure of adoption is used for dynastic purposes or to give the 'nobility status'. The issues are discussed in more detail in: Ignatowicz, J. and Nazar, M., Prawo rodzinne, Warszawa 2016, pp. 466-467. 
the decision of the Guardianship Court and not the will of the parties. On the other hand, it must be stressed that the court does not work ex officio, but upon request; therefore, it may be assumed that the will of the adopters is reflected by submitting such request.

Adoption is defined in modern law as the establishment of a legal and family relationship between the adopter and adoptee similar to the relationship that occurs between a parent and a child. ${ }^{7}$ Referring to the views of M. Andrzejewski, it is a way to formally ensure social fiction by officially establishing legal bonds similar to the relationship of parents and children. ${ }^{8}$ Therefore, a thought comes that the basic social function of adoption is to replace the missing family environment. ${ }^{9}$ Such a need occurs especially when the child becomes a natural or social orphan. The latter refers to the situation when at least one of the parents is alive but does not fulfil their parental duties. ${ }^{10}$

\section{Terminology}

The term 'adoption' has so far not been defined in the Family and Guardianship Code; the definition is included in the Penal Code. ${ }^{11}$ In compliance with the present wording of Article $115 \$ 22(\mathrm{a})$ of the Penal Code, adoption means acquisition of parental authority over the child by a person other than the one from whom the child comes. ${ }^{12}$ The authors of the amendments to the Penal Code in 2019 wanted to bring order to the terminology, as the term 'adoption' was used, but not defined

7 Adoption should be aimed at creating the conditions for the child identical to those in natural families. In particular, it is possible in the event when two married people jointly adopt the child and become the new parents therefor. However, joint adoption is not possible if two people are not married. See: Partyk, A., Specyfika przysposobienia wspólnego, LEX 2020.

8 Andrzejewski, M., Przysposobienie - podstawowe informacje i najważniejsze płaszczyzny sporów prawnych, in: Andrzejewski, M. and Łączkowska, M. (eds.), Prawne i pozaprawne aspekty adopcji, Poznań 2008, p. 8. See: resolution of the Supreme Court of 9 June 1976, III CZP 46/75, LEX No. 1966.

9 The Supreme Court explained that adoption is entirely aimed at ensuring the child's welfare. An important element - from the point of view of the child's welfare, apart from satisfying its needs in terms of maintenance and upbringing - is to create a family bond in the child's psyche by establishing the child-parent relationship between the child and the adoptive parents, having significant impact on its proper psychological and emotional development. See: judgement of the Supreme Court of 8 August 1967, I CR 120/67, LEX No. 762.

10 Strzebinczyk, J.F., Prawo rodzinne, Warszawa 2016, p. 331.

11 Act of 6 June 1997 - Penal Code, consolidated text: Dz.U. (Journal of Laws) of 2020, item 1086.

12 The provision was added by Article 1 point 1 of the Act of 16 October 2019 amending the act Penal Code and act - Code of Civil Procedure, consolidated text: Dz.U. (Journal of Laws) of 2019, item 2128 . 
in the legislation. On the other hand, in legal jargon, the term 'adoption' is used interchangeably with the 'obligation of maintenance. The aforementioned amendment introduced penalty for giving the child up for adoption by holders of parental responsibility (Article 211a $\$ 1$ of the Penal Code) and adopting the child from a person who is not its biological parent (211a $\$ 3$ of the Penal Code) ${ }^{13}$ In the grounds for the draft Act, it is stated that the concept of 'adoption' (...) should be considered (...) too [narrow] for the purposes of criminal law and criminalisation of behaviours stipulated in Article 211(a) of the Penal Code. The essence of wrongdoing is the willingness to acquire parental authority over the child and, from the point of view of such intention of the offender, it is irrelevant which legal and family measure he/she may use. The planned legal effect may be obtained through the adoption proceedings or, for instance, fictitious recognition of the child by a person pretending to be its biological parent. ${ }^{14}$ On the other hand, it should be noted that in other provisions of the Penal Code, the legislator consistently uses the term 'adoption'. For instance, pursuant to Article $115 \$ 11$ of the Penal Code, 'next of kin' is 'the person remaining in adoption-like relationship or their spouse'.

Adoption is not a uniform legal instrument, as it may create the legal and family relationship between the adopter and the adoptee, with effects on other family members, but also the legal and family relationship between the adopter and the adoptee themselves, without any effects on other family members. The following types of adoption are identified in the Family and Guardianship Code: simple adoption (adoptio minus plena), plenary adoption (adoptio plena) and full adoption (adoptio plenissima). ${ }^{15}$ On the other hand, the adoption resulting in the adoptee changing his/her place of residence in the Republic of Poland to reside in another state is referred to as 'foreign adoption'. In this context, it is more appropriate to use the term of 'intercountry adoption', as it relates to the terminology of international law. The provision in Article $114^{2}$ of the Family and Guardianship Code is usually applied by the Polish court, but it could be also used by a foreign court if the governing law is the Polish law. According to R. Zegadło, 'the term would potentially match the adoption ruled by a foreign court, for the acknowledgement of which it was applied in Poland: ${ }^{16}$ The above should be supplemented with the statement that the provision in Article $114^{2}$ of the Family and Guardianship Code does not

13 Mozgawa, M., Komentarz do art. 211 a k.k., in: Mozgawa, M. (ed.), Kodeks karny. Komentarz aktualizowany, LEX 2020.

Government draft act amending the act - Penal Code, print No. 3665.

15

Smyczyński, T., Prawo rodzinne i opiekuńcze, Warszawa 2018, p. 310.

16

Zegadło, R., Komentarz do art. $114^{2}$ k.r.o., in: Wierciński, J. (ed.), Kodeks rodzinny i opiekuńczy. Komentarz, LexisNexis 2014. 
concern cases of intercountry adoption to be potentially examined by the Polish court. An example could be the adoption of a child from another country by the applicants in Poland. Furthermore, the statutory definition of such adoption is the 'intercountry adoption. The term is present in the provisions of the Act of 9 June 2011 on support for families and the foster care system, which govern the preadoption procedure. ${ }^{17}$

\section{Historical background and assumptions of the provision in Article $114^{2}$ of the Family and Guardianship Code}

On the one hand, it may be claimed that by 19 October 1995, i.e. till the Act of 26 May 1995 amending the Act - Family and Guardianship Code and some other acts came into force ${ }^{18}$, the Polish law had not recognised the concept of the intercountry adoption. ${ }^{19}$ Nonetheless, it must be remembered that foreign adoptions could be ruled pursuant to Article 21 of the ratified Convention on the Rights of the Child. ${ }^{20}$ The scarcity of regulations on the intercountry adoptions, both in the Family and Guardianship Code from 1964 and earlier normative acts governing the institution of adoption after the Second World War, resulted from a small number of such adoptions. Legal scholars and commentators have observed that by the 1980s, the share of intercountry adoptions in the total number of adoptions ruled annually had not exceeded $2 \%{ }^{21}$ The development of the human rights protection system led to the situation that it eventually covered the institution of adoption. Together with the subsequent international initiatives more and more attention was paid to the need to protect the adopter. ${ }^{22}$ The first document aimed at protecting the child's welfare was the Declaration of the Rights of the Child, also referred to as the

17 Act of 9 June 2011 on support for families and the foster care system, consolidated text: Dz.U. (Journal of Laws) of 2020, item 821.

18 Act of 26 May 1995 amending the act - Family and Guardianship Code and certain other acts, consolidated text: Dz.U. (Journal of Laws) of 1995, no. 83 item 417.

19 Kalus, S. and Habdas, M., Family and succession law in Poland, Alphen aan den Rijn 2020, pp. 135136.

20 Convention on the Rights of the Child, 7 March 1990, E/CN.4/RES/1990/74.

21 The assessment whether the intended adoption was in compliance with the child's welfare was the decisive factor in accepting the application for adoption. See: Holewińska-Łapińska, E., Adopcje zagraniczne w praktyce polskich sądów, Warszawa 1998, pp. 70-75.

22 Łukasiewicz, R., Dobro dziecka a interesy innych podmiotów w polskiej regulacji prawnej przysposobienia, Warszawa 2019, p. 42. 
Declaration of Geneva, adopted on 23 February $1923 .{ }^{23}$ However, the Declaration was of a general nature; it was composed of five points concerning the issues that have a detrimental impact on the child's development. ${ }^{24}$ It served as a starting point for further and more intense protection of the welfare of the child deprived of its family environment. On 10 December 1948, the UN General Assembly adopted the Universal Declaration on Human Rights ${ }^{25}$; however, it was also general and the child's welfare was just one of the elements of its subject. The guarantee of human rights protection did not provide sufficient protection of the child's welfare; therefore, it was decided to pass a separate declaration, focusing on the interests of minors.

On 20 November 1959, the UN General Assembly adopted the Declaration of the Rights of the Child. ${ }^{26}$ In the context of the discussed issues, the sixth principle of the Declaration seems important, as it puts emphasis on the upbringing of the child in the family without being separated from its mother, and with the provision of particular care to children without a family. On the other hand, the protection of the welfare of the adoptee is noticeable within the following areas: possible separation of the child from its family, if necessary, and provision of care for children without the family. Another stage was to prepare the binding international agreement aimed at introducing the standard protection of the child's welfare. Therefore, on 20 November 1989, the Convention on the Rights of the Child, at times referred to as the 'world constitution of children's rights' was passed. It included framework solutions concerning the most important aspects of the adoptee's welfare protection. It should be recognised that pursuant to Article $20 \mathrm{sec}$. 2 of the Convention on the Rights of the Child, the States Parties are obliged to provide custody to children without the family environment. It may be in the form of placing the child in foster care, Kafali in Islamic law, adoption or, if necessary, in an appropriate institution established to provide custody to children. ${ }^{27}$

The aforementioned Article $114^{2}$ of the Family and Guardianship Code was introduced by amendment in 1995 to implement the provisions of Article 2(b) of the Convention on the Rights of the Child, in compliance with which the States

23 Geneva Declaration of the Rights of the Child adopted on 26 September 1924, League of Nations Official Journal, Special Supplement 21, p. 43.

24 Famine, disease, disability, social orphanhood, crime. See: Truszkowska-Wojtkowiak, M., Prawa dziecka a czas wolny, "Studia Gdańskie. Wizje i Rzeczywistość" 2013, Vol. 10, p. 401.

25 Universal Declaration of Human Rights, 10 December 1948, 217 A (III).

26 Declaration of the Rights of the Child, 20 November 1959, A/RES/1386(XIV).

27 Convention on the Rights of the Child, 20 November 1989, United Nations, Treaty Series, vol. 1577, p. 3. See: Article $20 \mathrm{sec}$. 3. The enumeration is purely illustrative. 
Parties should treat the adoption related to the relocation of the child into another country as the substitute means where the child may not be placed in foster care or adoptive home or if it is impossible to provide care for the child in the country of its origin. ${ }^{28}$ The above refers to the principle of subsidiarity of intercountry adoption. First of all, it should be considered whether custody or adoption would be the best for the child's welfare. Only then, when adoption proves the most convenient solution for the child, it is possible to assess which type of adoption would be better, in-country or intercountry. It means that not only the in-country adoption has the priority over the intercountry adoption, as it might seem, but also custody if it is the right solution for a given child. Furthermore, the Convention on the Rights of the Child provides for special requirements related to the intercountry adoption. In compliance with Article 21(c) of the Convention on the Rights of the Child, the child adopted from another country should be provided with a warranty bond and standard of living adequate to those that would be ensured in the case of the in-country adoption.

At this point, we should refer to the general condition of adoption. The requirement that the adoption should be for the child's welfare (Article $114 \$ 1$ of the Family and Guardianship Code) is determinative on whether the adoption could be effected. The child's welfare is of utmost importance and should be taken into account each time the child's custody is at stake ${ }^{29}$, thus also in the case of in-country and intercountry adoption. The child's welfare principle permeates adoption in all phases of its existence. The court - guided by the principle of the child's welfare decides whether the adoption relationship occurs, since the adoption is permissible only to ensure the child's welfare (Article $114 \$ 1$ of the Family and Guardianship Code). The court considers the child's interests also when ruling in cases related to adoption in the course of a legal relationship. The parental authority must be exerted by the adoptive parents as required to protect the child's welfare and social interests (Article $95 \$ 3$ of the Family and Guardianship Code). The above principle is also of key importance in the case of terminating the adoption. It is unacceptable

28 Bridge, C. and Swindells, H.Q.C., The modern law, Bristol 2003, pp. 294-295.

29 There is no legal definition of the term 'child's welfare'. In its decision of 13 December 2013, the Supreme Court stated that ' (...) the meaning should be given in specific circumstances, especially if they indicate to the existence of a situation, in which the child lives, requiring interference on the part of other entities, including the court. It is important to mention the right to protect life and health and all actions undertaken by other entities, who are obliged to provide appropriate conditions for peace, proper and undisturbed development, respect of dignity and participation in the process of deciding about the child's situation, and state that it is an inexhaustible set', see: decision of the Supreme Court of 13 December 2013, III CZP 89/13, LEX No. 2216088. 
that the child's welfare should suffer due to such termination (Article $125 \$ 1$ of the Family and Guardianship Code). ${ }^{30}$

Family law scholars believe that a decision on adoption must be in line with the child's welfare if there is a possibility of establishing a close emotional bond between the parties to the adoption relationship typical of the biological parents and children, when the adopter is capable of providing the appropriate upbringing and maintenance conditions for the child. ${ }^{31}$ At this point, it should be added that the evaluation of the adoptee's welfare may not be directed at the child's present situation only, but must also include its future. ${ }^{32}$

If there appears to be no chance of the child being adopted nationally, its adoption by persons living abroad may be considered. In such proceedings, the child's interests are of utmost importance. It is shown that the preservation of the national identity of the minor constitutes just one of the elements of the 'child's welfare. The court adjudicating in adoption cases should cooperate with the institutions specialised in the organisation of family foster care environments for children lacking the opportunity to live in natural families. When choosing appropriate solutions, the continuity of the child's upbringing and its ethical, religious, cultural and language continuity should be taken into consideration (Article $20 \mathrm{sec} .3$ of the Convention on the Rights of the Child). ${ }^{33}$

\section{Appropriate condition of a family foster care environment and the pre-adoption period}

One of the conditions determining the eligibility of the intercountry adoption is to establish that it is the only method for providing the child with the appropriate family foster care environment. ${ }^{34}$ At this point, the content of the term 'family foster care environment' used in Article $114^{2} \$ 1$ of the Family and Guardianship Code and the criteria allowing the evaluation of 'appropriateness' of such environment for the child should be determined. The adoption that entails the child's relocation to another country refers to the 'substitute means of child custody', which are discussed further in the article. The courts adjudicating in cases of adoption of the Polish child by foreigners are obliged to determine whether a given child may

\footnotetext{
30 Ignatowicz, J. and Nazar, M., op. cit., p. 467.

31 See: Stojanowska, W., Rozwód a dobro dziecka, Warszawa 1979, p. 35.

32 Decision of the Supreme Court of 22 June 2012, V CSK 283/11, LEX No. 1232479.

33 Ignaczewski, J., Kodeks rodzinny i opiekuńczy. Komentarz, Warszawa 2010, p. 666.

34 See: Article 20 sec. 3 of the Convention on the Rights of the Child.
} 
be adopted by an appropriate Polish family or placed in Polish foster care. Only if there appears to be no chance of the child being adopted nationally, its adoption by persons living abroad may be considered. ${ }^{35}$

The 'foster care environment' is created by an adoptive family and foster care family. What caused doubts among legal commentators was the fact that foster homes were treated as a family foster care environment. The custody exercised by the foster home is more institutionalised, hence it was proposed to exclude it from the scope of the discussed term. ${ }^{36}$ It is agreed that to ensure the child's welfare, family foster care environments have priority over institutions providing care for children. However, it is impossible not to agree with the opinion that no facility, even the best one, is able to ensure a family foster care environment.

At this point, it should be noted that the adoption proceedings are governed by the Act of 9 June 2011 on support for families and the foster care system. The implementation of adoption procedures and preparation of persons ready to adopt the child, known as the candidates for adopters, constitute an exclusive competence of the adoption centre. The exclusive competence of the adoption centre to implement the adoption procedures and training sessions means that none of the parties to such procedures may implement such procedures or train future adoptive parents. ${ }^{37}$

Pursuant to Article 167 of the said Act, the child may be eligible for adoption involving a change of its current place of residence in the Republic of Poland to reside in another state after exhausting all possibilities of finding the candidate for an adopter in the country, unless there is a relationship of consanguinity or affinity between the adopter and the adoptee, or the adopter has already adopted a brother or sister of the adoptee. It should be stressed that the adoption procedures related to the change of the child's current place of residence in the Republic of Poland to reside in another state may be implemented solely by the adoption centre authorised to cooperate with foreign central authorities or organisations or adoption centres licensed by foreign state authorities. ${ }^{38}$

The legal consequences of the choice of one of the aforesaid forms of a family foster care environment are different. The placement of a child in a foster family does not change its family status, hence, it is assumed that the child will maintain contact with its biological family. In such case, it is possible that the child will come

35 Ignaczewski, J., op. cit., p. 666.

36 The systemic interpretation would support such a solution. See: Holewińska-Łapińska, E., op. cit., pp. $70-75$.

37 Tryniszewska, K., Komentarz do art. 154 u.w.r., in: Tryniszewska, K. (ed.), Ustawa o wspieraniu rodziny i systemie pieczy zastępczej. Komentarz, LEX 2015.

38 Wilk, A., Komentarz do art. 168 u.w.r., in: Nitecki, S. (ed.), Ustawa o wspieraniu rodziny i systemie pieczy zastępczej. Komentarz, LEX 2018. 
back to its family. If it turns out that such return is impossible or would be harmful to the child and the child reached the age indicating development of strong bonds with the new family, the adoptive family would be the appropriate upbringing environment. ${ }^{39}$

The 1995 amendment introduced an additional condition in the form of a trial period, i.e. a mandatory period of personal contact between the potential adopters and the child at the child's current place of residence. In light of the judicial decisions of the Supreme Court, such a solution (...) has effect in the form of granting custody of the child for the duration of the adoption proceedings as collateral, which - if executed - will be equal to the placement of the child for upbringing. ${ }^{40}$ The point of this period is to verify whether the adopters were selected appropriately, to allow the parties to get to know each other and develop emotional bonds, and - above all - to ensure that the prerequisite to protect the child's welfare will be satisfied. ${ }^{41}$

The regulation in Article $120^{1} \$ 3$ of the Family and Guardianship Code stipulates that special care should be taken while selecting parties to the adoption relationship, as a result of which the adoptee will permanently leave the their home country. ${ }^{42}$ The literature shows that the last reservation concerning the place of the trial period is aimed at preventing the transfer of children abroad under the pretext that the trial period should take place in a foreign country, whereas in reality the objective is to avoid adoption proceedings before the Polish courts. ${ }^{43}$

Therefore, the view of J. Gajda should be shared, in accordance with which (...) a negative aspect of the solution adopted by the legislator may be the fact that not in every case, the adopter, sometimes having high personal and moral qualities, will be able to leave his/her place of residence, and abandon professional work for some period of time. It may cause that the potential adopter decides to give up the intention to adopt the child. However, the child's welfare requirement must be the priority, therefore, such a solution should be considered correct despite the fact that, for example, it may become the reason for limiting the number of foreign

39 Holewińska-Łapińska, E., op. cit., pp. 559-560. See: Gajda, J., Kodeks rodzinny i opiekuńczy. Komentarz, Warszawa 2000, p. 441.

40 Decision of the Supreme Court of 18 November 2014, II UK 52/14, "Orzecznictwo Sądu Najwyższego. Izba Pracy, Ubezpieczeń Społecznych i Spraw Publicznych” 2016, No. 5, item 64.

41 Andrzejewska, M., Osobista styczność $z$ dzieckiem $w$ przypadku spraw o przysposobienie międzynarodowe jako narzędzie chroniace dobro dziecka, "Białostockie Studia Prawnicze" 2017, No. 3, pp. 33-42.

42 Smyczyński, T., op. cit., p. 275.

43 Strzebinczyk, J.F., op. cit., p. 348. 
adoptions. ${ }^{44}$ It should be noted that the duration of the pre-adoption period has not been defined anywhere. Research has shown that in $75 \%$ of the examined cases, in which the period of contact was precisely defined, it was usually around two weeks but not longer than three weeks. ${ }^{45}$ The period seems short, especially when considering that in the case of intercountry adoption, the child and adoptive parents experience language and cultural barriers, apart from the ordinary barrier of strangeness ${ }^{46}$ In this context, the de lege ferenda demand is to precisely determine the minimum period of personal contact so as to increase safety of the adoptees by not allowing the so-called 'quick adoptions' and to provide the court with appropriate time to predict personal bonds between the parties.

\section{Principle of subsidiarity of intercountry adoption}

In compliance with the principle of subsidiarity of intercountry adoption, the adoption that entails the child's relocation to another country refers to the substitute means of child custody if the child may not be placed in foster care or an adoptive home or if it is impossible to provide care for the child in the country of its origin. It should be stressed that according to the Polish law, the principle of priority of adoption of Polish minors residing in Poland by Poles residing in Poland is effective. The adoption that causes the change of the adoptee's current place of residence in the Republic of Poland to reside in another state is allowable in the event when it is the only method for providing the adoptee with an appropriate family foster care environment.

The change of the place of residence may not be equal to the actual change of the child's whereabouts. ${ }^{47}$ Domicilium of a natural person is defined in Article 25 of the Civil Code. ${ }^{48}$ The child's domicilium is described in Article 26 of the Civil Code, in compliance with which it is the place of residence of the parents or the parent who has been vested with parental authority or entrusted with the exercise of such parental authority. ${ }^{49}$ If the parental authority is vested in both parents, who

44 Gajda, J., Przysposobienie dziecka w prawie polskim, in: Kasprzyk, P. (ed.), Prawo rodzinne w Polsce $i w$ Europie, Lublin 2005, p. 253.

Ciepła, H. et al., Kodeks rodzinny i opiekuńczy. Komentarz, Warszawa 2011, p. 882.

Andrzejewska, M., op. cit., p. 39.

Decision of the Supreme Court of 27 September 1990, III SA 688/90, LEX No. 10153. place of residence of all these persons will be this city/town. See: Nazaruk, P., Komentarz do art. 26 k.c., in: Ciszewski, J. and Nazaruk, P. (eds.), Kodeks cywilny. Komentarz, LEX 2019. 
live separately, the child's place of residence must be with the parent with whom the child stays permanently. ${ }^{50}$ The will of the Polish legislator was the principle of one place of residence (Article 28 of the Civil Code). Therefore, if the child's place of residence during the adoption proceedings is in a Polish city/town, Article $114^{2} \$ 1$ of the Family and Guardianship Code applies even if the child has stayed abroad for a longer period of time. In such case, despite the fact that the decision on adoption by a person living abroad does not cause the change of the country or even a city/ town where the child actually stays (having formal place of residence in Poland), the persons residing in Poland will have priority in adopting him or her. ${ }^{51}$

However, the priority principle of in-country adoption may not be automatically interpreted in a 'zero-one' manner. Other premises, such as the family situation of the child, its physical and psychological features, stage of development, and relationship with the adopters may also come into play. ${ }^{52}$ At this point, it should be determined that the child's welfare is a decisive factor. It was also the ruling of the Supreme Court, which stated in the decision of 5 July 2006 that (...) although in light of Article $114^{2} \$ 1$ of the Family and Guardianship Code, the foreign adoption should be actually treated as ultima ratio, the child's interest and welfare as well as the possibility of its full and harmonious development may require, in a given case, rejection of the priority principle of in-country adoption. ${ }^{53}$

On 29 May 1993, the Convention on Protection of Children and Cooperation in Respect of Intercountry Adoption was passed in Hague. ${ }^{54}$ The Convention confirmed the principle of subsidiarity with respect to intercountry adoptions, in compliance with which this kind of adoption should be treated as the ultima ratio measure. Furthermore, Article 4 of the said Convention also includes the conditions for intercountry adoptions. First of all, competent authorities in the country of origin must determine that the child is eligible for adoption. ${ }^{55}$ After examining the possibilities of placing the child in the country of its origin, the state authorities

50 If the child does not stay permanently with either of parents, its place of residence is determined by the Guardianship Court (Article $26 \$ 2$ of the Civil Code).

51 The literature contains a view that the purpose of such regulation was to prevent the situations when the child, whose place of residence is Poland, will be taken abroad to facilitate the adoption procedure for foreigners. More information: Holewińska-Łapińska, E., in: Smyczyński, T. (ed.), System prawa prywatnego. Prawo rodzinne i opiekuńcze. Tom 12, Warszawa 2011, p. 558.

52 Adoption by a person residing abroad, who is the child's relative and is emotionally involved with the child may serve as an example.

53 Decision of the Supreme Court of 5 July 2006, IV CSK 127/06, LEX No. 232819.

54 Hague Conference on Private International Law, Hague Convention on the Protection of Children and Co-operation in Respect of Intercountry Adoption, 29 May 1993, 33.

55 It means that it is first necessary to state that it is the adoptive family, and not, for example custody, that will be the appropriate environment for the child. 
must determine whether the intercountry adoption would best match the child's interests.

The child's welfare is also protected by way of appropriate control of the candidates for adopters. The host state must conclude that the future adopters [parents] are eligible, which is provided for by Article 5(a) of the aforementioned Convention. It is important to note in this regard that the collaboration between the authorities of the country of origin and the host state does not aim only at the determination that the adopters are eligible for the child's adoption in general, but that they are appropriate for this particular child.

The discussed Convention is an attempt to establish a minimum standard for protecting the child's welfare in this area. Even though its general values are unquestionable, legal commentary shows certain disputes that arise in the practice of intercountry adoptions between the State Party to the Convention and the state not participating in the Convention. This often leads to the differentiation of standards of the child's welfare protection. ${ }^{56}$

As already mentioned, Article $114^{2}$ of the Family and Guardianship Code introduced the priority principle, according to which the in-country adoptions prevail over the intercountry adoptions, yet with certain exceptions mentioned in $₫ 2$, which stipulates that the aforesaid principle does not apply if the adopter is the child's relative or affinity; or if the adopter has already adopted a brother or sister of the child. Apparently, certain limitations regarding intercountry adoptions do not refer to inter-family adoptions or adoptions aimed at the maintenance of family bonds. It seems that in the case of joint adoption by spouses, the discussed condition is fulfilled if one of the spouses is the child's relative or affinity. What is interesting, neither the degree or line of kinship or affinity are defined in the Family and Guardianship Code, which means that the kinship or affinity may be direct or secondary and the degree of kinship or affinity remote.

It must be agreed that the child's relative or affinity does not privilege the foreign applicant. The foreign applicant's request is not each time granted priority. In the case of a conflict between the request for a decision on adoption submitted by the entities mentioned in $114^{2} \$ 2$ of the Family and Guardianship Code and the request of the Polish candidate, the Guardianship Court, guided by the child's interests, should choose the adopter who may best guarantee the due performance of the obligations resulting from the adoption. ${ }^{57}$

56 Zieliński, A., Nowa konwencja haska w sprawie przysposobienia międzynarodowego, "Państwo i Prawo" 1993, No. 9, pp. 3-13.

57 Strzebinczyk, J.F., op. cit., p. 346. 


\section{Adoption by homosexual couples}

The issue of admissibility of intercountry adoption by homosexual couples was one of the controversial aspects that emerged during the debate on the Convention on Protection of Children and Cooperation in Respect of Intercountry Adoption. However, it must be stressed that, in this context, same-sex adoptions only concern such cases when both the country where the adopters reside and the child's country of origin allow such adoptions. Therefore, it might be concluded that the country (its courts), whose legislation does not allow adoptions by homosexual couples, may invoke fundamental principles of its own legal framework (public policy clause).

Adoptions by homosexual couples have been legalised in 15 countries, including Belgium (2006), Denmark (2010), France (2013), Iceland (2006), the Netherlands (2001), Norway (2009), Spain (2005), Sweden (2003) and in some parts of the United Kingdom (2005). ${ }^{58}$ In Poland, the legal and social situation of LGBT people $^{59}$ is evaluated differently. The social situation concerns such issues as the tolerance level towards LGBT individuals, extent of violence against LGBT individuals in society as well as the LGBT culture and media. On the other hand, the legal situation includes such issues as a possibility of formal recognition by the legislator of a same-sex relationship (marriage or partnership) or adoption of a child under the care of the state facility or stepson/stepdaughter by a LGBT person or couple. ${ }^{60}$

The advocates of adoption, including intercountry adoption, by same-sex couples use the argument of equal rights, i.e. they claim that there is no place in civilised societies for ethnic, gender or sexual orientation discrimination. The refusal to grant equal rights to homosexual partners may be a manifestation of discrimination. ${ }^{61}$ Furthermore, there is considerable evidence that same-sex couples have equally good competence as parents as heterosexual couples. ${ }^{62}$ Another issue is that a child needs a family. It should be also remembered that adopted children,

58 The provisions allowing the adoption by homosexual couples have been effective in England and Wales since 2005, in Scotland since 2009 and in Ireland since 2013.

59 The abbreviation that stands for Lesbian, Gay, Bisexual, Transgender. See: American Psychological Association, https://www.apa.org/topics/lgbt (accessed 28.07.2020).

60 For the legal and social situation of LGBT people in Poland see Wikipedia, Sytuacja prawna i społeczna osób LGBT w Polsce, https://pl.wikipedia.org/wiki/Sytuacja_prawna_i_społeczna_ osób_LGBT_w_Polsce (accessed 28.07.2020).

61 In other words, both homosexual and heterosexual couples deserve the same right to adopt children. See: judgement of the Constitutional Tribunal of 21 March 2005, P 5/04 and judgement of the Supreme Administrative Court of 19 February 2020, II OSK 932/18, LEX No. 3022271 (in particular, the manner of understanding the principle of equality).

62 Averett, P. et al., An evaluation of gay/lesbian and heterosexual adoption, "Adoption Quarterly" 2009, Vol. 12, pp. 129-151. 
including children adopted by same-sex partners, do not come from full and happy families. Majority of them come from orphanages or foster care families, or remain under the custody of single mothers who are unable to provide care for children. A (traditional) family or homosexual couple may prove the best possible solution. ${ }^{63}$ What is interesting is the fact that thanks to the American legislation allowing adoption by same-sex couples, 65,000 children have already found their homes.

The literature also includes arguments against adoption by same-sex couples. One of them is that homosexual relationships are not as lasting as heterosexual relationships. A characteristic feature of such relationships is also promiscuity, which is not so typical of heterosexual relationships. Another thing is frequent identity changes during the relationships. The key argument against adoption by same-sex couples is still the welfare of the child that - as proven by science and life experience - needs a mother and father for its proper development. ${ }^{64}$

On the other hand, one of the main principles of the EU is the principle of subsidiarity. It refers to the issues, which - due to their nature - will be resolved or achieved more efficiently at the EU level. Adoption by same-sex couples is the issue that should be resolved at the national level, without any pressure on citizens coming from more traditional societies. It is also worth mentioning that parenthood by homosexual couples is sometimes contradictory to the religious views of many people. Legalisation of adoption by LGBT people could offend professed values and the role of religion, which is the moral foundation of society. Another issue is democracy, which not always produces the expected results. We should respect the choice of the majority, even if they are against adoption by same-sex couples. ${ }^{65}$

Currently, it is rather unlikely that Poland will introduce any changes related to the situation of LGBT individuals in this regard. It is also worth mentioning that in July 2020, President Andrzej Duda signed draft constitutional amendments prohibiting adoption by same-sex couples. The provisions of family law will be incorporated into the Constitution: a minor may be adopted solely for the purpose of ensuring his/her welfare; the minor may be adopted solely by a married couple pursuant to the definition included in Article 18 of the Constitution, i.e. a man and a woman only. The Parliament is planning to add one more provision, which is not

63 Shapiro, L.M., Inferring a right to permanent family care from the United Nations Convention on the Rights of the Child, the Hague Convention on Intercountry Adoption, and selected scientific literature, "Washington and Lee Journal of Civil Rights and Social Justice" 2008, Vol. 15, No. 1, pp. 191-226.

64 To krzywda dla dzieci, "Niedziela Ogólnopolska" 2011, No. 49, p. 33.

65 Arguments for and against gay adoption, Debating Europe, https://www.debatingeurope.eu/focus/ arguments-gay-adoption/\#.XyEffy0lD7m (accessed 29.07.2020). 
currently in family law, i.e. the minor may not be adopted by any person who is in cohabitation with another person of the same sex. ${ }^{66}$

\section{Intercountry adoption in numbers}

The number of adoptions in Poland remains at the same level and includes around 3,000 children per year. ${ }^{67}$ On the other hand, the number of Polish children adopted by foreign couples is decreasing, which is shown in the following table.

Table 1: Statistics of intercountry adoptions in Poland in 2012-2018. ${ }^{68}$

\begin{tabular}{|l|c|c|c|c|c|c|c|}
\hline Country of adoptive parents & 2012 & 2013 & 2014 & 2015 & 2016 & 2017 & 2018 \\
\hline Austria & 0 & 0 & 5 & 0 & 0 & 0 & 0 \\
\hline Belgium & 10 & 0 & 17 & 10 & 6 & 3 & 0 \\
\hline France & 13 & 21 & 24 & 6 & 4 & 2 & 1 \\
\hline Spain & 9 & 21 & 13 & 17 & 12 & 4 & 1 \\
\hline The Netherlands & 13 & 6 & 5 & 8 & 1 & 1 & 1 \\
\hline Ireland & 0 & 0 & 0 & 0 & 1 & 0 & 0 \\
\hline Canada & 2 & 0 & 1 & 1 & 0 & 1 & 0 \\
\hline Germany & 2 & 5 & 2 & 10 & 2 & 2 & 0 \\
\hline Sweden & 12 & 17 & 13 & 11 & 12 & 3 & 0 \\
\hline USA & 38 & 44 & 54 & 85 & 55 & 26 & 14 \\
\hline Great Britain & 0 & 0 & 1 & 1 & 0 & 0 & 0 \\
\hline Italy & 156 & 209 & 176 & 177 & 124 & 56 & 11 \\
\hline TOTAL & 255 & 323 & 311 & 326 & 217 & 98 & 28 \\
\hline
\end{tabular}

Since 2003, over 4,000 children were adopted by foreign families. The largest number of children from Polish orphanages went to Italy $(25,000)$ and the USA

66 Ambroziak, A., Dudy gra wyborcza zakazem adopcji. "To okrutne. Prezydent odbiera dzieciom prawo do rodziny", 06.07.2020, OKO.press, https://oko.press/dudy-gra-wyborcza-zakazem-adopcji/ (accessed 28.07.2020).

67 Statistical data from the Ministry of Labour, Family and Social Affairs, in the period 2006-2015.

68 Source: statistical data of the Ministry of Labour, Family and Social Affairs, elaboration by the Department of Policy of the Ministry of Labour, Family and Social Affairs, based on statistical data from the reports of adoption centres responsible for intercountry adoptions), https://www.gov.pl/ web/rodzina/667informacje-statystyczne (accessed 09.07.2019). 
(700). ${ }^{69}$ In 2013, the number of intercountry adoptions worldwide decreased threefold in comparison with 2003, which is illustrated in the following figure.

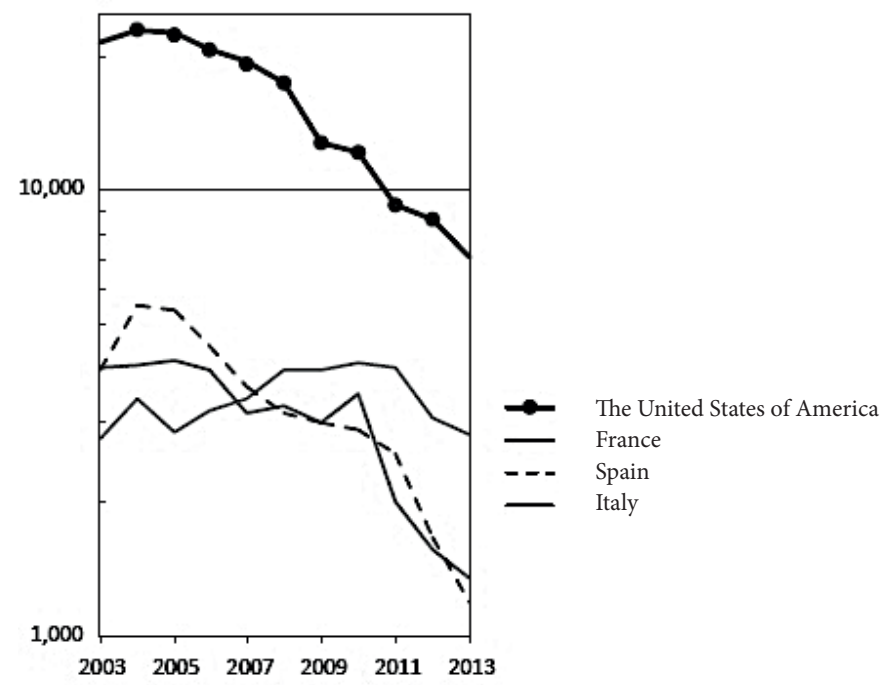

Figure 1: Statistics on intercountry adoptions worldwide, in major host states in the period 2003-2013. ${ }^{70}$

To compare, the Western European countries and Scandinavia are rather conservative when it comes to adoption of their citizens abroad. ${ }^{71}$ Between 1999 and 2015, 1,254 Polish children were adopted by adopters in the USA, whereas only 2 were adopted by adopters in Finland, 7 in France, and 2 in Italy in the same period. ${ }^{72}$ Foreign families usually adopt children in the 7 to 10 age group.$^{73}$

69 More information about the reasons for this phenomenon may be found in: Knuiman, S. et al., Children without parental care in Poland: foster care, institutionalization and adoption, "International Social Work" 2015, Vol. 58 (1), pp. 142-152.

70 Source: Selman, P., Key tables for intercountry adoption: receiving states 2003-2013 and states of origin 2003-2013, Newcastle University 2014.

71 More information: Mignot, J., Why is intercountry adoption declining worldwide?, "Population \& Societies" 2015, No. 519, p. 3.

72 Krawczak, A., Adopcje zagraniczne - gdzie tkwi problem, 25.01.2017, Krytyka Polityczna, http:// krytykapolityczna.pl/kraj/adopcje-zagraniczne-gdzie-tkwi-problem/ (accessed 09.07.2020).

73 Pawłowska, D., Droga do domu. Adopcje w Polsce i na świecie, 06.02.2017, wyborcza.pl, http://biqdata.wyborcza.pl/biqdata/7,159116,22156657,droga-do-domu-adopcje-w-polsce-i-na-swiecie. html (accessed 09.07.2020). 
As the practice shows, the number of countries where citizens apply for adoption of Polish children has been decreasing recently. According to the Ministry's data, it is evident that in the first half of 2017, 41 intercountry adoptions were performed in total. To compare, in the similar period one year before, 109 children who could not find their permanent homes in Poland were adopted by foreign families. ${ }^{74}$ Such a significant decline is caused by the tightening of the eligibility criteria for adopters and adoptees with respect to intercountry adoptions and the reduction in the number of centres authorised to effect such adoptions.

Generally speaking, it may be stated that the issues of intercountry adoption are part of global problems related to poverty and inequality. The children who are included in the international adoption system usually come from developing countries, whereas the adoptive parents usually live in developed countries. The meaning of intercountry adoptions is the subject of many disputes, where the opinions differ depending on the adopted perspective, including the context of origin or the context of adoption..$^{75}$ The decreasing number of intercountry adoptions worldwide and the increasing criticism, together with accusations of child trafficking, led to the change of the mass adoption system to a more elitist arrangement, where childless couples and people from rich countries who are single may embody their conviction that they have the right to have a child and build a family. What is interesting, some countries give their consent to intercountry adoption, whereas others, with similar social, political and economic conditions, disagree. ${ }^{76}$ Additionally, the analysis of this phenomenon shows that it is caused by the division of the world into the centre and peripheries as well as by the system of global inequalities that trigger international migrations. Such global inequalities include, in particular, social and cultural gender inequalities. The literature confirms that privileged women who are aware of their rights and are domiciled in developed countries adopt children from countries where the cultural position of women is generally low and their weak bargaining position is further weakened by the pressure resulting from the hardship of a biological mother. ${ }^{77}$ Nonetheless, far too little is said about adoption in the context of the welfare of the child, which this measure should serve.

74 Świętochowska, E., Trudniej o adopcje zagraniczne, 29.01.2018, Gazeta Prawna, https://prawo. gazetaprawna.pl/artykuly/1100746,adopcje-zagraniczne-prawo.html (accessed 04.07.2020).

75 See: Lind, J. and Johansson, S., Preservation of the child's background in in - and intercountry adoption, "The International Journal of Children's Rights" 2009, Vol. 17, No. 2, pp. 235-260.

76 Albański, Ł. and Krywult-Albańska, M., Adopcje międzynarodowe jako zaniedbany obszar badań nad migracjami, "Studia Migracyjne - Przegląd Polonijny" 2016, Vol. 3 (161), pp. 369-390.

77 McCreery Bunkers, K. et al., International adoption and child protection in Guatemala. A case of the tail wagging the dog, "International Social Work" 2009, Vol. 52 (5), pp. 649-660. 


\section{Conclusion}

Adoption of a child is a form of foster parenthood, within the framework of which the child become a full member of the adopters' family. Obviously, it is the type of adoption that determines whether the child will 'enter' the family of the adopter and become its part just like a biological child. In the case of half-adoption, its effects concern both the adopter and the adoptee (and its descendants). The child may be eligible for adoption connected with the changing of its current place of residence in the Republic of Poland to reside in another state after exhausting all possibilities of finding the candidate for adopter of the child in the country, unless there is a relationship of consanguinity or affinity between the adopter and the adoptee, or the adopter has already adopted a brother or sister of the adoptee.

Intercountry adoption is not an alternative to in-country adoption. The child's welfare principle permeates adoption at all stages of its existence. All emerging problems and dilemmas related to intercountry adoption should be mainly resolved by specifying the provisions governing such intercountry adoption, ${ }^{78}$ for the purpose of protecting the child's interests in the most efficient way.

In recent years, the number of intercountry adoptions of Polish minors has been decreasing. This is the result of, among other things, the tightening of the eligibility criteria for both parents and children subject to intercountry adoption. The issues of intercountry adoptions are more and more often present in social, legal and political discourse regarding intercountry adoption. They are also part of the poverty and inequality context. However, what remains unchanged is the fact that all adoption decisions must be taken to safeguard the child's welfare.

\section{References}

Albański, Ł. and Krywult-Albańska, M., Adopcje międzynarodowe jako zaniedbany obszar badań nad migracjami, "Studia Migracyjne - Przegląd Polonijny" 2016, No. 3(161).

Ambroziak, A., Dudy gra wyborcza zakazem adopcji. To okrutne. Prezydent odbiera dzieciom prawo do rodziny, 06.07.2020, OKO.press, https://oko.press/dudy-gra-wyborcza-zakazem-adopcji/.

Andrzejewska, M., Osobista styczność $z$ dzieckiem w przypadku spraw o przysposobienie międzynarodowe jako narzędzie chroniące dobro dziecka, "Białostockie Studia Prawnicze" 2017, No. 3.

78 More information: request of the Polish Commissioner for Human Rights and the Ombudsman for Children submitted with the Minister of Justice to specify the provisions on intercountry adoptions dated 08.11.2017, IV.7023.8.2017. 
Andrzejewski, M., Przysposobienie - podstawowe informacje i najważniejsze płaszczyzny sporów prawnych, in: Andrzejewski, M. and Łączkowska, M. (eds.), Prawne i pozaprawne aspekty adopcji, Poznań 2008.

Averett, P. et al., An evaluation of gay/lesbian and heterosexual adoption, "Adoption Quarterly" 2009, Vol. 12.

Bridge, C. and Swindells, H.Q.C., The modern law, Bristol 2003.

Ciepła, H. et al., Kodeks rodzinny i opiekuńczy. Komentarz, Warszawa 2011.

Arguments for and against gay adoption, Debating Europe, https://www.debatingeurope. eu/focus/arguments-gay-adoption/\#.XyEffy0lD7m.

Gajda, J., Kodeks rodzinny i opiekuńczy. Komentarz, Warszawa 2000.

Gajda, J., Przysposobienie dziecka w prawie polskim, in: Kasprzyk, P. (ed.), Prawo rodzinne w Polsce i w Europie, Lublin 2005.

Holewińska-Łapińska, E., 'Adopcje zagraniczne' w praktyce polskich sądów, Warszawa 1998.

Holewińska-Łapińska, E., in: Smyczyński, T. (ed.), System prawa prywatnego. Prawo rodzinne i opiekuńcze. Tom. 12, Warszawa 2011.

Ignaczewski, J., Kodeks rodzinny i opiekuńczy. Komentarz, Warszawa 2010.

Ignatowicz, J. and Nazar M., Prawo rodzinne, Warszawa 2016.

Kalus, S. and Habdas, M., Family and succession law in Poland, Alphen aan den Rijn 2020.

Knuiman, S. et al., Children without parental care in Poland: foster care, institutionalization and adoption, "International Social Work" 2015, Vol. 58 (1).

Kolańczyk, K., Prawo rzymskie, Warszawa 2007.

Krawczak, A., Adopcje zagraniczne - gdzie tkwi problem, 25.01.2017, Krytyka Polityczna, http://krytykapolityczna.pl/kraj/adopcje-zagraniczne-gdzie-tkwi-problem/.

Kuryłowicz, M., Rozwój historyczny rzymskiej adopcji, "Studia Iuridica Lublinensia” 2011, No. 16.

Lind, J. and Johansson, S., Preservation of the child's background in in - and intercountry adoption, “The International Journal of Children's Rights” 2009, Vol. 17, No. 2.

Łukasiewicz, R., Dobro dziecka a interesy innych podmiotów w polskiej regulacji prawnej przysposobienia, Warszawa 2019.

McCreery Bunkers, K. et al., International adoption and child protection in Guatemala. A case of the tail wagging the dog, "International Social Work" 2009, Vol. 52 (5).

Mignot, J., Why is intercountry adoption declining worldwide? "Population \& Societies" 2015, No. 519.

Mozgawa, M., Komentarz do art. 211a k.k., in: Mozgawa, M. (ed.), Kodeks karny. Komentarz aktualizowany, LEX 2020.

Nazaruk, P., Komentarz do art. 26 k.c., in: Ciszewski, J. and Nazaruk, P. (eds.), Kodeks cywilny. Komentarz, LEX 2019. 
Partyk, A., Specyfika przysposobienia wspólnego, LEX 2020.

Pawłowska, D., Droga do domu. Adopcje w Polsce i na świecie, 06.02.2017, wyborcza.pl, http://biqdata.wyborcza.pl/biqdata/7,159116,22156657,droga-do-domu-adopcje-wpolsce-i-na-swiecie.html.

Selman, P., Key tables for intercountry adoption: receiving states 2003-2013 and states of origin 2003-2013, Newcastle University 2014.

Shapiro, L.M., Inferring a right to permanent family care from the United Nations Convention on the Rights of the Child, the Hague Convention on Intercountry Adoption, and selected scientific literature, "Washington and Lee Journal of Civil Rights and Social Justice” 2008, Vol. 15, No. 1.

Smyczyński, T., Prawo rodzinne i opiekuńcze, Warszawa 2018.

Stojanowska, S., Rozwód a dobro dziecka, Warszawa 1979.

Strzebinczyk, J.F., Prawo rodzinne, Warszawa 2016.

Świętochowska, E., Trudniej o adopcje zagraniczne, 29.01.2018, Gazeta Prawna, https:// prawo.gazetaprawna.pl/artykuly/1100746,adopcje-zagraniczne-prawo.html.

To krzywda dla dzieci, "Niedziela Ogólnopolska” 2011, No. 49, p. 33.

Truszkowska-Wojtkowiak M., Prawa dziecka a czas wolny, "Studia Gdańskie. Wizje i Rzeczywistość" 2013, Vol. 10.

Tryniszewska, K., Komentarz do art. 154 u.w.r., in: Tryniszewska, K. (ed.), Ustawa o wspieraniu rodziny i systemie pieczy zastępczej. Komentarz, Wyd. II, LEX/el. 2015.

Wilk, A., Komentarz do art. 168 u.w.r., in: Nitecki, S. (ed.), Ustawa o wspieraniu rodziny i systemie pieczy zastępczej, Komentarz, LEX/el. 2018.

Zegadło, R., Komentarz do art. $114^{2}$ k.r.o., in: Wierciński, J. (ed.), Kodeks rodzinny i opiekuńczy. Komentarz, LexisNexis 2014.

Zieliński, A., Nowa konwencja haska w sprawie przysposobienia międzynarodowego, "Państwo i Prawo" 1993, No. 9.

\section{CITATION}

Kamińska, K., Intercountry adoption in Polish family law, “Acta Iuris Stetinensis” 2020, No. 3 (Vol. 31), 41-61, DOI: 10.18276/ais.2020.31-03. 